\title{
Tubuh dan Relasi Gender: Wacana Pascakolonial Dalam Novel “The Scarlet Letter"Karya Nathaniel Hawthorne
}

\author{
${ }^{1} \mathrm{M}$. Yuseano Kardiansyah, ${ }^{2}$ Andriadi, ${ }^{3}$ Azizah Mahmud, ${ }^{4}$ Dzikrina Dian, ${ }^{5}$ Elmy Selfiana Malik, ${ }^{6}$ Nur \\ Innayah Ganjarjati
}

Alumnus Program Pascasarjana S2 Ilmu Sastra UGM Angkatan 2012

${ }^{1}$ Fakultas Sastra dan Ilmu Pendidikan Universitas Teknokrat Indonesia

1yuseano@teknokrat.ac.id

\begin{abstract}
Abstrak
Penelitian ini menganalisa wacana pascakolonial mengenai tubuh dan relasi gender di dalam sebuah novel berjudul "The Scarlet Letter" karya Nathaniel Hawthorne yang menceritakan obsesi terhadap moralitas, menggambarkan penindasan terhadap gender, hukuman terhadap pendosa, juga rasa bersalah dan pengakuan dosa seorang individu. Tujuan penelitian ini adalah untuk menguak sisi perlawanan terhadap konstruksi kolonial yang masih berlaku di dalam tatanan dan norma sosial masyarakat yang dicerminkan di dalam novel tersebut. Dengan menerapkan pendekatan pascakolonialisme dan metode yang mendukung analisis secara dekonstruktif, dapat dibuktikan bahwa novel tersebut mengungkapkan perlawanan terjajah (perempuan) yang ada di balik sikap dan praktiknya yang seakan patuh pada kekuasaan penjajah (masyarakat dan dominasi laki-laki).
\end{abstract}

Kata Kunci: Wacana Pascakolonial, Tubuh, Relasi Gender, Dekonstruksi, Konstruksi Kolonial

\begin{abstract}
This research analyzes postcolonial discourse about body and gender relation in Nathaniel Hawthorne's The Scarlet Letter that tells about obsession toward morality, gender oppression, punishment for sinner, guilty feeling dan individual sin confession. The objective of this research is to reveal the resistance sides toward colonial construction that still exist in society's social order and norm reflected in that novel. By applying postcolonialism approach and deconstruction method, it is proven that The Scarlet Letter depicts colonized (women) resistance behind its attitude and practice that seems submissive to the power of colonizer (society dan men's domination).
\end{abstract}

Key Words: Postcolonial Discourse, Body, Gender Relation, Deconstruction, Colonial Construction

\section{Pendahuluan}

Merunut sejarahnya, tema cerita yang ada dalam genre prosa pada ranah kesusastraan sangatlah beragam dan kreatif. Selayaknya genre sastra lainnya, ragam cerita yang ditampilkan pada karya sastra prosa ini pun mengandung isuisu tertentu yang biasanya berkaitan dengan ruang lingkup sosial tempat diciptakannya karya sastra itu berada. Salah satu isu yang telah berkembang hingga saat ini adalah yang berkaitan dengan status dan posisi perempuan di dalam tatanan masyarakat tertentu atau apa yang secara umum disebut dengan isu feminisme. Hal ini tentu saja berkaitan dengan respon terhadap fenomena sosial yang terjadi di tengah-tengah kehidupan masyarakat tertentu, dan tujuan diciptakannya karya sastra yang mengangkat isu feminis ini antara lain dapat berupa satire atau sindiran, perlawanan, atau bahkan sebagai dukungan terhadap tatanan sosial yang berlaku terhadap posisi dan status perempuan tersebut.

Di dalam sejarah kesusastraan, arah kecenderungan wacana feminisme yang ditulis oleh para penulis prosa sebenarnya telah mulai menggelora semenjak masa transisi dari periode Augustus menuju periode Romantisme (17501780) sampai dimulai dan berakhirnya periode Romantisme itu sendiri (1880-1830) di Inggris. Hal tersebut dipicu oleh keadaan yang membuat hak dan ruang kebebasan wanita begitu sempit. Be- 
berapa nama seperti Ann Radcliffe, Jane Austen, Mary Wollstonecraft, Maria Edgeworth, dan Susan Ferrier adalah penulis-penulis yang cukup dikenal pada masanya. Sementara itu, sebagai ex-koloni Inggris, di Amerika periode Romantik ini dimulai pada tahun 1820 dan berakhir pada 1860. Nama-nama seperti Walt Whitman, Nathaniel Howthorne, Herman Melville, Edgar Allan Poe, dan Emily Dickinson adalah penulis-penulis yang cukup populer di Amerika pada masa itu (VanSpanckeren, 1994: 36).

Dari beberapa nama penulis yang telah disebutkan di atas, Nathaniel Hawthorne adalah novelis yang karya-karyanya sangat berpengaruh, tidak hanya dalam khasanah kesusastraan Inggris-Amerika saja tetapi juga kesusastraan dunia. Salah satu novelnya berjudul "The Scarlet Letter" (1850) adalah yang sangat populer dan telah diterjemahkan ke dalam beberapa bahasa hingga saat ini (termasuk bahasa Indonesia). Kebanyakan cerita Hawthorne mengambil latar kaum Puritan yang ada di daerah New England, tidak terkecuali The Scarlet Letter (VanSpanckeren, 1994: 37). Novel ini menceritakan cinta terlarang yang emosional antara seorang pendeta Athur Dimesdale dengan seorang wanita cantik bernama Hester Prynne yang dianggap sebagai pendosa karena telah hamil oleh orang yang bukan suaminya, yang mana di dalam cerita ini Dimesdale sebagai pria yang bertanggung jawab atas kehamilan tersebut dirahasiakan aibnya hingga akhir cerita. Berlatar belakang sosial di Boston sekitar tahun 1650 selama awal masa kolonisasi Puritan, novel ini menyoroti obsesi 'Calvinis' terhadap moralitas, menggambarkan penindasan terhadap gender, hukuman terhadap pendosa, juga rasa bersalah dan pengakuan dosa seorang individu. Dalam hal ini, The Scarlet Letter adalah novel yang subversif dan bahkan berani. Novel ini mengangkat isu-isu yang dianggap tabu dan biasanya ditekankan pada abad 19 di Amerika, seperti pengalaman demokrasi yang memberi kebebasan pada perilaku individu, terutama pada kebebasan seksual dan agama.

Dalam hal ini, keberadaan novel The Scarlet Letter bisa dikatakan sebagai bentuk respon terhadap tatanan dan norma sosial yang kemungkinan telah terpengaruh oleh konstruksi agama yang dianut oleh masyarakat kaum Puritan. Penekanan terhadap kebebasan individu di dalam novel ini adalah sebuah ekspresi perlawanan terhadap represi yang diberikan oleh masyarakat terhadap individu atas nama moralitas dan normanorma agama. Di sini, setidaknya ada dua fokus bahasan yang dapat menjadi sorotan berkenaan dengan isu gender dan individualitas yang dimunculkan dalam novel The Scarlet Letter. Tentu saja, jika dikaitkan dengan isu feminisme, novel ini tidak akan terlepas dari relasi antar gender yang dicerminkan oleh Hester Prynne (tokoh utama) dan pengaruh tatanan sosial terhadapnya selaku seorang individu dan dominasi laki-laki terhadapnya selaku seorang perempuan. Berkenaan dengan hal tersebut, hal penting yang patut digarisbawahi adalah gambaran dominasi laki-laki yang tampak selalu mengatur dan menentukan kehidupan Hester sebagai wanita yang ditampilkan di dalam novel tersebut.

Di samping itu, fokus penting lainnya yang bisa ditujukan pada isu-isu tersebut adalah eksistensi konstruksi sosial terhadap tubuh seorang Hester Prynne sebagai hukuman atas dosa yang telah ia perbuat, yang mana ia harus menggunakan symbol huruf " $A$ " berwarna merah yang melekat di dadanya sebagai tanda bahwa ia telah melakukan dosa. Hal ini sangat identik dengan pernyataan Michel Foucault (dalam Suyono, 2002: 392) tentang fenomena tubuh yang patuh dan otomatik, yang ia tujukan sebagai respon-nya terhadap banyaknya institusi yang memiliki prosedur kegiatan penghukuman gaya penjara pada akhir abad 17 dan awal-awal abad 18. Dalam hal ini, dengan mengatakan adanya teknik-teknik pengkondisian manusia yang sama antara institusiinstitusi dengan penjara seperti itu, sebenarnya ia tidak terfokus pada penjara atau persoalan kriminalitas. Suyono (2002: 393) menyatakan bahwa proyek utama analisis Foucault dalam "The Discipline and Punish" (1977) tersebut cenderung mengarah kepada analisis atas teknik-teknik pengkondisian yang terjadi pada diri manusia Eropa. Di sini, Foucault memiliki tesis bahwa memasuki abad ke-18 disiplin tidak hanya berlaku untuk mengubah perilaku para pelaku kriminal saja, akan tetapi juga perilaku individu Eropa secara umum. Berkenaan dengan hal tersebut, tampaknya teknik-teknik seperti itu juga diberlakukan terhadap koloni-koloni jajahan mereka, tid- 
ak terkecuali Amerika yang pada saat itu merupakan tanah jajahan Inggris.

Selain itu, satu aspek penting lain yang perlu dipertimbangkan dalam mengkaji novel ini antara lain adalah bahwa novel ini juga mengangkat konstruksi Puritanisme dalam menggambarkan tatanan dan norma hidup yang berlaku di dalam lingkungan sosialnya. Seperti yang telah diketahui, bahwa Puritanisme adalah paham ajaran agama yang dicetuskan di Inggris pada abad ke-16, dan menjadi semakin kuat hingga abad ke-17 (Samekto, 1998: 33). Pada akhirnya, paham ini tersebar luas kedalam koloni-koloni yang sedang dikuasai oleh Inggris pada saat itu, termasuk Amerika. Oleh karena itu, di sini novel The Scarlet Letter ini dapat diposisikan sebagai novel pascakolonial, karena pada dasarnya novel ini diciptakan di negara yang pernah memiliki pengalaman sebagai negara terjajah dan dibuat setelah masa penjajahan di negara tersebut telah berakhir. Seperti halnya teori tentang pascakolonial yang diuraikan Lo dan Helen (1998) dalam Faruk (2007: 15) sebagai berikut:

"Teori pascakolonial mencakup tiga kemungkinan pilihan perhatian: (a) pada kebudayaan masyarakatmasyarakat yang pernah mengalami penjajahan Eropa, baik berupa efek penjajahan yang masih berlangsung sampai pada masa pascakolonial maupun kemungkinan transformasinya ke dalam bentuk-bentuk yang disebuat neokolonialisme (internal maupun global), (b) respons perlawanan atau wacana tandingan dari masyarakat terjajah maupun yang lainnya terhadap penjajahan itu, tanpa menghilangkan perhatian pada kemungkinan adanya ambiguitas atau ambivalensi, dan (c) segala bentuk marginalitas yang diakibatkan oleh segala bentuk kapitalisme".

Oleh karena itu, dapat disimpulkan bahwasanya novel ini menggambarkan kondisi dan kecenderungan masyarakat yang pernah terjajah, di mana novel ini sengaja dibuat untuk memberikan respons terhadap sebuah bentuk penjajahan yang masih berlangsung setelah masa penjajahan itu sendiri telah berakhir. Dalam hal ini, pemaksaan paham suatu agama di dalam kehidupan individu dan dominasi kaum laki-laki terhadap perempuan adalah bentuk penjajahan yang dimaksud.

Berkenaan dengan hal tersebut, secara khusus tulisan ini membahas sebuah penelitian terhadap novel The Scarlet letter yang menggambarkan muatanmuatan kolonialisme di dalamnya. Sebagai novel pascakolonial, novel ini dijadikan sebuah objek material yang digunakan untuk menguak sisi perlawanan terhadap konstruksi kolonial yang masih berlaku di dalam tatanan dan norma sosial masyarakat yang dicerminkan di dalam novel tersebut. Pendekatan yang diambil dalam penelitian ini tentu saja adalah pendekatan pascakolonial, dan sejalan dengan pandekatan tersebut, Faruk (2007: 17-18) menjelaskan bahwa secara metodologis pendekatan ini akan mengarahkan penelitian terhadap usaha-usaha berikut:

Mengungkapkan represi kekuasaan penjajah yang terselubung dibalik sikap dan praktiknya yang seakan tidak mengandung pretensi kekuasaan atau politik.

Mengungkapkan represi kekuasaan penjajah di balik praktik dan sikap masyarakat terjajah yang seakan sudah bebas atau mengarah pada usaha pembebasan dari kekuasaan penjajah itu.

Mengungkapkan represi perlawanan terjajah yang ada di balik sikap dan praktiknya yang seakan patuh pada kekuasaan penjajah.

Menegaskan posisi teori dan kritik pascakolonial sebagai aktivitas pemberdayaan masyarakat terjajah (agency) dan sebagai aktivitas penghapusan segala bentuk penjajahan (dekolonisasi).

Secara garis besar, Faruk (2007: 18) menekankan bahwa metode ini dapat disebut sebagai metode dekonstruksi yang beroperasi dengan setidaknya dua cara. Pertama, melakukan analisis tekstual terhadap suatu karya (dalam hal ini The Scarlet Letter), guna menemukan kecenderungan tematiknya, asumsi-asumsi dasarnya, dan sekaligus menemukan sarana-sarana retorik yang digunakannya yang mungkin bertentangan dan dapat menunda (suspending) dan membuat asumsiasumsi dasar itu terpecah (ruptured). Kedua, melakukan analisis tekstual terhadap teks-teks yang dimarjinalkan untuk mendesentralisasi (decentered) kesatuan tematik wacana dominan dalam karya tersebut. Oleh karena itu, metode ini 
diyakini mampu membongkar wacana perlawanan yang terkandung dalam novel ini, khususnya wacana yang menunjukan perlawanan terhadap nuansa kolonial seperti dominasi lakilaki terhadap wanita dan represi konstruksi sosial terhadap wanita.

\section{Pembahasan}

Berdasarkan novel tersebut, dapat diketahui bahwa novel ini memiliki teknik bercerita orang ketiga maha tahu (omniscient) yang menempatkan narator di luar cerita pokok walaupun sang tokoh 'Aku' ini adalah tokoh nyata (ada) di dalam novel ini dan memiliki peran sebagai pencerita di dalam novel ini. Di sini, cerita tentang The Scarlet Letter ini dibentuk sebagai cerita sejarah yang diceritakan kembali oleh sang narator (Aku). Dari setiap narasi dan dialog yang ditemukan dalam novel ini, ditemukan dua hal menarik berkaitan dengan bagaimana nuansa kolonial dimunculkan dalam novel ini, yaitu gambaran relasi gender yang ditampilkan dan juga keberadaan tubuh individu yang ter-represi oleh konstruksi sosial. Di mana kedua hal tersebut bisa menunjukkan betapa kuatnya nuansa kolonial di dalam novel ini.

\section{Tubuh dan Konstruksi Sosial}

Novel ini secara garis besar memberikan perhatian khusus pada gejala-gejala tubuh tokoh utama dalam ceritanya, yaitu penampilan fisik tokoh Hester Pryne, baik penampilan tubuhnya maupun atribut-atribut yang melekat pada tubuhnya. Dalam novel ini, tubuh Hester Pryne digambarkan sebagai tubuh yang tinggi dan anggun, yang mana hal tersebut ditambah dengan deskripsi secara fisik lainnya seperti rambut, wajah, alis, dan mata sebagai penekanan sosok perempuan ideal pada unumnya. Hal itu tercermin di dalam narasi berikut:

Wanita muda tersebut tinggi, dengan garis tubuh yang anggun. Ia memiliki rambut berwarna hitam tebal, sangat indah sampai memantulkan sinar matahari. Wajah cantiknya berbeda dengan yang biasa, alisnya tebal dan matanya gelap. Ia terlihat sangat feminin,....(Hawthorne, 2007: 55)

Berdasarkan kutipan tersebut, dapat dilihat bagaimana tubuh seorang wanita diidealkan oleh penulis di dalam ceritanya. Jika dilihat dalam perspektif feminis, dapat dikatakan bahwa sebagai seorang laki-laki Hawthorne telah memberikan prototipe-nya terhadap apa itu wanita cantik dan feminine. Hal-hal demikianlah yang sering diperdebatkan oleh kalangan masyarakat tertentu karena prototipe seperti ini sering dianggap pemicu diskriminasi terhadap perempuan yang tidak memiliki fisik ideal seperti yang digambarkan oleh Hawthorne dalam novel ini. Akan tetapi, jika mempertimbangkan aspek lain di mana sebagai penulis Hawthorne juga harus memenuhi harapan pembacanya akan sosok ideal sang tokoh utama wanita, pekerjaan Hawthorne ini secara umum dapat dimaklumi.

Akan tetapi, hal tersebut bukanlah fokus utama dalam analisis ini karena hal penting yang sangat difokuskan adalah nuansa kolonial yang ditampilkan dalam novel ini. Sebagaimana tubuh Hester Prynne yang telah didefinisikan sebelumnya, dalam hal ini nuansa kolonial yang tertangkap berkaitan dengan konsep tubuh tersebut terlihat pada atribut yang melekat pada tubuh Hester Prynne itu sendiri. Hal itu digambarkan dalam narasi sebagai berikut:

Namun mata semua orang yang pernah mengenalnya tertuju pada satu titik HURUF SCARLET yang terbordir indah di dadanya. Huruf itu menyebabkan dampak seperti mantera, membawa Hester Prynne keluar dari hubungan biasa dengan duniawi. (Hawthorne, 2007: 55)

Tidak mengerti jalan pikiran si terhukum, pendeta yang lebih tua, yang telah mempersiapkan diri untuk menghadapi acara ini, menyuruh para penonton untuk tidak berhenti mengutuk dosa yang telah dilakukan Hester dengan simbol huruf scarlet di dada. (Hawthorne, 2007: 73)

Setiap hari ia tetap akan menghadapi pengadilan dari masyarakat. Hari-hari yang akan ia lalui adalah beban yang harus ditanggung......Mereka yang masih muda dan suci akan diajarkan untuk memandangnya dan huruf scarlet di dadanya....sebagai sosok, tubuh dari dosa yang nyata. (Hawthorne, 2007: 87)

Selain hukuman penjara yang didapat Hester sebagai kompensasi atas dosa yang telah ia 
Poetika : Jurnal Ilmu Sastra

Vol. V No. 1, Juli 2017
DOI 10.22146/poetika.25065

ISSN 2338-5383 (print) ; 2503-4642 (online) lakukan, suatu hal yang menarik adalah hukuman sosial berupa huruf scarlet yang harus disandang di dadanya selama hidupnya. Dalam hal ini, huruf scarlet adalah tanda bagi seorang pendosa dalam masyarakat puritan. Dengan tanda itu, maka sosok Hester akan selalu dikenal sebagai sosok pendosa bagi masyarakat puritan, tempat di mana Hester hidup dan bersosialisasi.

Berdasarkan hal tersebut, dapat dilihat bagaimana pola atau teknik pemenjaraan dalam bentuk pengkondisian tubuh secara sosial seperti yang dijelaskan oleh Foucault sebelumnya digambarkan dalam novel ini. Walaupun telah melewati hukuman penjara, hukuman yang lebih berat justru didapat oleh Hester dalam kehidupan sosialnya. Dalam hal ini, kebebasan tubuh Hester sebagai seorang individu telah terenggut secara tidak langsung oleh konstruksi sosial yang represif. Gambaran tubuh ideal yang dimiliki Hester hancur ketika hukuman sosial (yang dipengaruhi oleh paham agama) berupa huruf scarlet disandangkan di dadanya. Kecantikan berubah menjadi kehinaan melalui sebuah konstruksi sosial yang direpresentasikan oleh sebuah huruf scarlet yang diatributkan kepada seorang wanita bernama Hester Prynne. Dalam hal ini, tubuh Hester dikondisikan sebagai prototipe seorang pendosa dengan mengenakan huruf scarlet tersebut.

Akan tetapi, di sisi lain ada suatu titik di mana resistensi pun ditemukan dalam novel ini terkait dengan konstruksi sosial yang dikondisikan pada tubuh Hester sebagai seorang individu. Hal tersebut berawal dari kutipan berikut ini:

Ini mungkin luar biasa, dengan dunia seperti ini, wanita tersebut sebenarnya bebas untuk kembali ke tanah kelahirannya atau ke daratan Eropa lain, dan di sana ia dapat menyembunyikan identitasnya di bawah penampilan yang baru, bagai lahir seperti manusia baru....Sungguh luar biasa jarena wanita itu tetap tinggal di tempat yang disebutnya rumah, di mana ia hanya menjadi contoh keburukan. (Hawthorne, 2007: 88)

Secara bertahap, pekerjaan tangan Hester-lah yang menentukan gaya di kota tersebut. Walaupun wanita ini telah mengalami penderitaan dan penghinaan, juga rasa curiga dari orangorang, jelas bahwa ia kini menghabiskan berjam-jam untuk menyelesaikan pekerjaannya. Pakaian yang dikenakan oleh orang-orang dalam pesta atau upacara, dihiasi oleh sulaman dari tangannya yang berdosa. (Hawthorne, 2007: 91)

Namun demikian, pakaian Hester sendiri terbuat dari bahan yang paling kasar, dengan warna pudar, dan hanya terdapat satu hiasan - huruf scarlet, yang akan dikenakannya sampai akhir hidup. (Hawthorne, 2007: 91-92)

Berdasarkan kutipan tersebut di atas, dapat dilihat bagaimana sosok Hester lebih memilih untuk tinggal di tempat di mana ia dihina dan dikucilkan karena dosanya. Dengan memilih untuk tetap di lingkungan itu, secara otomatis, Hester pun harus menerima konsekuensi untuk mematuhi norma dan aturan yang berlaku di lingkungan tersebut. Sebagaimana yang telah dijelaskan sebelumnya, di tempat itu tubuh Hester sebagai seorang individu dikondisikan dan dikonstruksi sebagai prototipe seorang pendosa dengan huruf scarlet sebagai simbolnya.

Berdasarkan salah satu fungsi analisis pascakolonial yang telah dijelaskan sebelumnya, yaitu untuk mengungkapkan represi perlawanan terjajah yang ada di balik sikap dan praktiknya yang seakan patuh pada kekuasaan penjajah. Dalam novel tersebut, bertahannya Hester di New England dan berusaha untuk bersosialisasi dengan keterampilan yang ia punya adalah sebuah pilihan untuk sebuah kepatuhan. Walaupun huruf scarlet harus ia kenakan sampai akhir hayatnya sebagai sebuah konsekuensi. Hal menarik yang patut diperhatikan adalah bahwa ternyata masyarakat juga pada akhirnya seakan bergantung dengan keterampilan dan kreatifitas Hester dalam menyulam. Hal itu tentu saja berbanding terbalik dengan penghinaan dan rasa curiga yang kerap diberikan masyarakat terhadapnya. Dalam hal ini, wacana tersebut seakan ingin menyatakan keberhasilan Hester dalam memasuki ranah sosial ditempat yang semestinya Hester akan merasa terhina, direndahkan, dan dikucilkan. Secara halus, sikap kepatuhan Hester terhadap konstruksi sosial yang berlaku terhadap dirinya dan tubuhnya rupanya telah membuat pandangan masyarakat terhadapnya tidak lagi solid, akan tetapi sudah mencair. 
Selain itu, keputusan Hester untuk bertahan di tempat yang mengharuskan pengkondisian terhadap tubuhnya itu secara tidak langsung akan memaksanya untuk terus mengenakan lambang pendosa, yaitu huruf scarlet di dalam kehidupan sosialnya. Dalam hal ini, dapat dikatakan bahwa langkah yang diambil Hester itu adalah sebuah keberanian untuk melawan paradigma masyarakat puritan terhadap simbol huruf scarlet yang diberikan kepadanya. Sikap Hester ini seakan ingin menyatakan bahwasanya ia tidak terpengaruh dengan konstruksi sosial tersebut, di mana orang akan merasa Hester adalah seorang yang hina karena melekatnya huruf scarlet di dadanya. Akan tetapi, bagi Hester hal itu tak akan memengaruhi dirinya dalam menjalani hidupnya. Dalam hal ini, sikap Hester tersebut menunjukan bahwa ide pemenjaraan tubuh melalui pengkondisian konstruksi sosial terhadap tubuh Hester sendiri akan gagal. Hal tersebut terjadi karena perlawanan Hester terhadap ide kolonial tersebut hanya berlaku bagi pihak pengkondisinya, tidak berlaku bagi individu pemilik tubuh yang dikondisikan. Di sini, bentuk resistensi Hester terhadap konstruksi kolonial tersebut dilakukan dengan sikap yang seakan patuh pada kekuasaan penjajah. Padahal, dibalik kepatuhan tersebut ada perlawanan yang kuat sehingga dapat membuat hegemoni kolonialisme tak lagi berlaku pada ranah jajahannya.

\section{Relasi Gender}

Secara garis besar, novel ini tentu saja berisi cerita tentang relasi sang tokoh utamanya yaitu Hester Prynne dengan lingkungan sosial, yang mana dalam novel ini tokoh-tokoh mayoritas yang ditampilkan adalah tokoh laki-laki. Tanpa memberikan prasangka tertentu terhadap Hawthorne sebagai penulis novel ini, selayaknya novel-novel lain, relasi gender pun hadir di dalam novel ini. Di sini, kehidupan sosial yang dicerminkan tampak terdominasi oleh kontrol lakilaki selaku perwakilan atas nama masyarakat dan agama, layaknya dunia sosial adalah dunia lakilaki, oleh karenanya peraturan harus ditegakkan oleh laki-laki pula. Hal itu tergambarkan oleh beberapa karakter seperti 'Pendeta Arthur Dimmesdale', 'Dokter Roger Chillingworth', 'Gubernur Bellingham', 'Pendeta Tua Wilson', dan 'Sipir Brackett'. Dalam analisis ini, ada dua karakter sentral yang difokuskan, yaitu Arthur
Dimmesdale dan Roger Chillingworth. Selain karena mereka adalah tokoh utama dalam cerita ini, mereka juga adalah sosok yang paling dominan dalam penggambaran relasi gender pada novel ini.

Dalam novel ini, dominasi laki-laki dapat terlihat tentu saja karena kelemahan sosok Hester Prynne sebagai sosok perempuan juga terlihat dengan cukup jelas. Sosok Hester yang lembut, peka, dan feminine ini semakin tersudut karena statusnya yang dianggap sebagai pendosa. Ketidakberdayaan Hester sebagai seorang perempuan seakan dimunculkan dengan mengedepankan ketidakmampuan Hester untuk mengakui siapa ayah dari anak yang telah dilahirkannya itu. Hal tersebut tergambar dalam kutipan berikut:

Janganlah melindunginya lagi, beranikan dirimu untuk menyebutkan namanya!.....Hester menggelengkan kepalanya. (Hawthorne, 2007: 71-72)

"Tidak akan pernah," jawab Hester Prynne, ia tidak menatap Mr. Wilson, melainkan langsung ke mata pendeta muda Dimmesdale.(Hawthorne, 2001: 72)

Berdasarkan kutipan tersebut, tatapannya kepada Dimmesdale seakan menunjukan perasaan peka yang membuatnya tak kuasa untuk melibatkan Dimmesdale sebagai orang yang seharusnya bertanggung jawab atas bayi yang dilahirkannya. Sementara itu, sebagai seorang pendeta yang dicintai umatnya, tak akan pernah ada kecurigaan terhadapnya karena modal sosial Dimmesdale sebagai laki-laki penegak ajaran agama telah dapat melindunginya secara tidak langsung, sepanjang ia tidak mengakui dosanya sendiri kepada umatnya.

Sementara itu, dominasi laki-laki lainnya tampak dalam karakter Roger Chillingworth sebagai seseorang yang sebenarnya masih berstatus suami dari Hester Prynne akan tetapi tidak diketahui oleh masyarakat. Hal tersebut terlihat dalam kutipan berikut:

Bahkan bila aku membayangkan sebuah balas dendam, apa yang lebih baik dari pada membiarkan objek balas dendamku tetap hidup - .....Sehingga mereka akan dapat merasakan penghinaan....Saat ia berkata demikian, ia menyentuh huruf scarlet dengan jari telunjuknya, yang tampaknya akan menusuk dada Hester 
Prynne. Hester menggerakan tubuhnya. Pria tersebut menyadari gerakan Hester, dan tersenyum. (Hawthorne, 2007: 79)

Pria itu menarik sebuah kursi dan duduk di dekat si wanita. Hester gemetar, karena ia merasakan kekejaman ketika pria tersebut melakukan itu. (Hawthorne, 2007: 80)

Berdasarkan kutipan tersebut, dapat dilihat bahwa bagaimana karakter Chillingworth telah mendominasi dan mengalahkan Hester dalam cerita ini. Rasa takut Hester terhadap Chillingworth tergambarkan dengan tak berdayanya Hester ketika Chillingworth mengungkapkan rasa bencinya dan dengan sengaja menyentuh huruf scarlet yang melekat di dada Hester. Selain itu, rasa takut itu semakin terlihat dengan gemetarnya tubuhnya saat merasakan kekejaman Chillingworth ketika ia duduk didekat Hester.

Berdasarkan analisis tersebut, dapat terlihat sebuah implikasi nuansa kolonial yang terjadi dalam relasi gender yang tercermin di dalam novel The Scarlet Letter ini. Dalam hal ini, analisis tersebut membuktikan adanya sebuah konstruksi kolonial yang berbentuk dominasi yang dilakukan oleh gender laki-laki terhadap gender perempuan. Hal ini tentu saja berawal dari stereotipe tentang karakteristik perempuan yang selalu dianggap lemah dan statusnya lebih rendah dari kaum laki-laki. Stereotipe tersebut seakan dibenarkan dengan digambarkannya sosok Hester yang tak kuasa untuk mengakui siapa ayah dari bayi yang dilahirkannya, dan juga tak berdayanya Hester atas perlakuan tidak menyenangkan Chillingworth yang ditujukan kepadanya. Oleh karena itu, relasi gender dalam novel ini ditampilkan dengan nuansa dominasi lakilaki terhadap wanita di dalam suatu ruang lingkup sosial yang memang memiliki dasar konstruksi sosial yang begitu kuat dan dominan.

Akan tetapi, seperti analisis yang telah dilakukan sebelumnya, suatu resistensi pun ditemukan dalam relasi gender pada novel ini terkait dengan dominasi laki-laki terhadap sosok perempuan yang bernama Hester Prynne ini. Hal tersebut berawal dari kutipan berikut ini:
Pembenaran satu-satunya berada pada fakta bahwa ia tidak dapat menemukan suatu cara untuk menyelamatkan pendeta dari kehancuran. Dalam tekanan seperti itu ia telah membuat pilihan. Ia memutuskan untuk memendam kesalahannnya. (Hawthorne, 2007: 187)

Intinya, Hester Prynne bertemu dengan mantan suaminya, dan akan melakukan apa saja untuk mencegah pria itu memangsa korbannya yang tampaknya sudah berada dalam genggaman. (Hawthorne, 2007: 188)

Di sini, dapat dilihat bahwa apa yang sebenarnya terjadi justru dibalik dominasi seorang pendeta Dimmesdale yang begitu dicintai dan dihormati masyarakat di dalam cerita ini, terkuak sebuah fakta di mana laki-laki ini adalah sosok yang rentan dan lemah. Hal ini dapat disimpulkan pada sebuah fakta di mana ia sebagai seorang lakilaki tidak kuasa untuk mengakui dan bersedia bertanggung jawab atas apa yang ia lakukan terhadap Hester. Secara umum, tidakan yang kerap dilakukan olehnya di dalam cerita adalah berusaha memendam aib dan rasa bersalahnya itu di balik hegemoni agama yang dapat ia lakukan kepada masyarakatmnya.

Berdasarkan kutipan di atas dan korelasinya terhadap kutipan sebelumnya, posisi Hester dalam cerita ini justru dapat dikatakan sangat mulia, bahkan mungkin sama mulianya dengan ceramah agama yang selalu dilakukan Dimmesdale terhadap umatnya. Sejak awal, justru Hester Prynne-lah sosok yang walaupun sekilas tampak seperti telah terdominasi oleh sosok pendeta Dimmesdale dalam kehidupan sosialnya, namun secara tidak langsung memiliki kekuatan tersendiri di balik kelembutan dan kelemahan yang tampak dari sisi fisiknya. Hester, dalam hal ini dengan rasionalnya bersedia melindungi nama baik pendeta Dimmesdale dari kehancuran guna menyelamatkan sosok pendeta itu dari aib perzinahan yang telah dilakukannya, yang justru akan membuat kehormatan seorang pembesar agama dan nilai-nilai agama yang identik dengan pendeta dan umat puritan akan hancur secara bersamaan.

Selain itu, berdasarkan kutipan terakhir di atas tampak pula bagaimana sosok perempuan seperti Hester rela untuk melawan rasa takunya kepada Chillingworth guna melindungi pendeta Dimmesdale yang sudah berada pada am- 
Poetika : Jurnal Ilmu Sastra

Vol. V No. 1, Juli 2017
DOI 10.22146/poetika.25065

ISSN 2338-5383 (print) ; 2503-4642 (online) bang balas dendam yang sebenarnya sudah dilakukan oleh Chillingworth terhadapnya. Dalam cerita ini, Dimmesdale tidak mengetahui bahwasanya Chillingworth adalah musuh yang sedang berusaha melampiaskan dendamnya karena telah merusak rumah tangganya dengan Hester. Oleh karena itu, Hester berusaha untuk melindungi Dimmesdale dari Chillingworth dengan berbagai cara.

Di sini, dapat terlihat justru relasi gender di mana sosok perempuan yang tersubordinasi dan terdominasi oleh sosok laki-laki dalam novel ini dibongkar dan diputarbalikan. Sosok Hester yang pada awalnya digambarkan sebagai sosok lemah lembut yang hanya bisa menerima nasibnya karena kepengecutan pendeta Dimmesdale untuk mengakui perzinahan mereka, pada akhirnya tampak mejadi sosok mulia, tegar, dan berani yang rela mengorbankan dirinya untuk menjaga nama baik dan keselamatan pendeta Dimmesdale. Selain itu, dominasi sosok Dimmesdale terhadap Hester yang terlihat pada awalnya, akhirnya ditepiskan karena dalam hal ini justru posisi Hester yang kerap melindungi Dimmesdale dari kesalahan dan bahaya dalam kehidupannya, menguatkan sosok Hester sebagai wanita yang rasional, kokoh, dan berani. Berbanding terbalik dengan Dimmesdale yang justru terlihat pengecut, lemah, dan rentan, di mana hidupnya secara tidak langsung selalu digantungkan kepada sosok Hester Prynne di dalam novel ini.

Selain itu, gambaran relasi antara sosok Hester sebagai perempuan dan laki-laki pun terjadi pada dirinya dan karakter Roger Chillingworth. Berikut ini adalah kutipan yang menggambarkan relasi tersebut:

"Tapi, Hester, siapa pria yang ada di antara kita? Siapa dia?”....’Jangan tanyakan padaku!" jawab Hester Prynne, sambil menatap tajam. " Kau tidak akan pernah tahu!” (Hawthorne, 2007: 81-82)

"Kau berkata seolah-olah kau adalah pengampun," kata Hester, tampak marah dan murka, "tapi kata-katamu bagaikan terror!" (Hawthorne, 2007: 83)

"Aku harus membuka rahasia kita," jawab Hester, dengan tegas. "Ia harus tahu siapa kau sebenarnya. Entah apa yang akan terjadi kemudian. (Hawthorne, 2007: 196)

"Dan aku juga mengasihanimu," balas Hester Prynne," karena kebencian yang dapat mengubah pria bijak dan baik menjadi setan!...Biarkan Tuhan yang mengurusnya! Kukatakan, tidak akan ada kebaikan untuknya, untukmu, untukku, yang.....(Hawthorne, 2007:197)

Di sini, dapat dilihat bahwa apa yang sebenarnya terjadi dibalik dominasi Chillingworth dalam relasinya kepada Hester sebagai perempuan, terkuak sebuah fakta di mana laki-laki ini adalah sosok yang rentan dan lemah layaknya pendeta Dimmesdale. Hal ini dapat disimpulkan pada sebuah fakta di mana seorang laki-laki yang pada umumnya dipandang sebagai sosok yang rasional dan tegar, tampak begitu emosional dan sensitif. Secara umum, tindakan yang kerap dilakukan olehnya di dalam cerita adalah berusaha untuk melampiaskan dendamnya terhadap Dimmesdale dan mengancam Hester untuk merahasiakan identitasnya.

Berdasarkan kutipan di atas dan korelasinya terhadap kutipan sebelumnya, posisi Hester dalam cerita ini justru dapat dikatakan sebagai sosok yang selalu berusaha terlepas dari dominasi Chillingworth yang berusaha diberikan terhadapnya. Sejak awal sosok perempuan yang tampak seperti telah terdominasi oleh sosok dokter Chillingworth ini secara jelas memiliki kekuatan tersendiri di balik kelembutan dan kelemahan yang tampak dari sisi fisiknya. Hester, dalam hal ini, dengan beraninya bersedia melindungi pendeta Dimmesdale dari bahaya yang akan menimpanya jika identitasnya ia ungkapkan kepada Chillingworth, walaupun pada saat itu Hester sendiri tidak tahu apakah keberaniannya tersebut justru akan membahayakan dirinya atau tidak. Keberanian Hester untuk melawan dominasi Chillingworth juga diberikan ketika, pada akhirnya, ia harus membuka kedok sang dokter karena Hester melihat bahwa tindakan Chillingworth terhadap Dimmesdale sudah sangat membahayakan sehingga ia membatalkan janjinya untuk tidak membocorkan rahasia tentang siapa sebenarnya Chillingworth itu.

Dalam hal ini, secara jelas bahwasanya 
sosok Hester sebagai perempuan telah mampu terbebas dari dominasi seorang laki-laki seperti Chillingworth yang kerap mengancam dan mengintimidasi dirinya atas kesalahan yang telah ia lakukan bersama Dimmesdale. Hal tesebut juga dipertegas dengan tampilnya sosok Hester yang sangat rasional dalam menanggapi permasalahan yang sedang menyelimuti dirinya, Dimmesdale, dan Chillingworth, yang terlihat pada kutipan terakhir di atas. Dalam hal ini, sosok perempuan yang kerap dipandang sebagai sosok yang emosional, sensitif, dan irrasional pun seakan terpecahkan, di mana pada akhirnya sosok Hester yang direndahkan dan terdominasi oleh sosok laki-laki mampu terlepas dari itu semua, dan berpikir secara rasional dan berani. Hal ini justru berbanding terbalik dengan sosok Chillingworth yang sangat emosional dan sensitif, di mana kehidupannya justru secara tidak langsung bersandar pada kesediaan Hester untuk merahasiakan identitasnya dan kebenciannya terhadap orang ketiga di dalam rumah tangganya.

\section{Kesimpulan}

Dari pemaparan di atas, dapat ditarik kesimpulan bahwa novel The Scarlet Letter berisi tentang wacana-wacana yang menggambarkan adanya resistensi dari pihak terjajah terhadap pihak penjajah. Resistensi tersebut dapat dilihat dalam konteks tubuh dengan konstruksi sosial serta pada relasi gendernya.

Pertama, melalui pemakaian huruf scarlet di dada sebagai hukuman yang harus diterimanya, Hester justru menunjukkan resistensinya dengan memilih melanjutkan hidup dan tetap berkreatifitas di tengah masyarakat yang merepresinya, masyarakat Puritan. Kepatuhannya dengan menerima segala konsekuensi hidup di tengah konstruksi sosial masyarakat sosial mengantarkan keberhasilan resistensi dirinya sekaligus kegagalan represi terhadapnya melalui sikap yang ditunjukan oleh Hester terhadap masyarakat, yang menyebabkan rasa ketergantungan masyarakat tersebut terhadapnya.

Kedua, penggambaran karakter feminin yang tercermin dari segi fisik maupun perilaku karakter utama dalam novel ini, tidak menutup kemungkinan untuk perempuan tersebut mampu membalikkan dominasi laki-laki dalam relasi antar gender yang digambarkan. Pembalikan dominasi laki-laki tersebut ditemukan pada perannya yang sentral dalam memegang kendali tindakan-tindakan yang dilakukan oleh tokoh Dimmesdale dan Cilingworth. Implikasi tindakan yang diperankan oleh Dimmesdale dan Cilingworth dalam alur cerita dibangun atas konsekuensi kehadiran Hester. Dalam hal ini Hester yang seakan-akan berada dalam posisi yang terdominasi oleh kehadiran sosok laki-laki di dalam novel ini, justru mampu mengimbangi bahkan melampaui peran laki-laki yang seakan mendominasi sosok perempuan tersebut.

Oleh karena itu, dapat disimpulkan bahwa sebagai novel pasca-kolonial The Scarlet Letter mengungkapkan represi kekuasaan penjajah yang terselubung dibalik sikap dan praktiknya yang seakan tidak mengandung pretensi kekuasaan atau politik. Novel ini mengungkapkan represi kekuasaan penjajah di balik praktik dan sikap masyarakat terjajah yang seakan sudah bebas yang direpresentasikan oleh konstruksi puritanisme peninggalan masa kolonial Inggris. Melalui analisis yang telah dilakukan, pendekatan pascakolonialisme terbukti mampu untuk mengungkapkan represi perlawanan terjajah (perempuan) yang ada di balik sikap dan praktiknya yang seakan patuh pada kekuasaan penjajah (masyarakat dan dominasi laki-laki). Hal ini menegaskan posisi teori dan kritik pascakolonial sebagai aktifitas pemberdayaan masyarakat terjajah (agency) dan sebagai aktifitas penghapusan segala bentuk penjajahan (dekolonisasi).

\section{Daftar Pustaka}

Faruk. 2007. Belenggu Pasca-Kolonial: Hegemoni \& Resistensi dalam Sastra Indonesia. Yogyakarta: Pustaka Pelajar.

Hawthorne, Nathaniel. 2007. The Scarlet Letter (ed. Terjemahan). Yogyakarta: Narasi.

Samekto. 1998. Ikbtisar Sejarah Kesusastraan Inggris. Jakarta: Daya Widya.

Suyono, Seno Joko. 2002. Tubuh Yang Rasis: Telaah Kritis Michel Foucault Atas Dasar-Dasar Pembentukan Diri Kelas Menengah Eropa. Yogyakarta: Pustaka Pelajar. 
Poetika : Jurnal Ilmu Sastra

Vol. V No. 1, Juli 2017
DOI 10.22146/poetika.25065

ISSN 2338-5383 (print) ; 2503-4642 (online)

VanSpanckeren, Kathryn. 1994. Outline of American Literature (Revised Edition). Published By the United States Departement of State 